4. On the Tertiary Coals of New Zealand. By W. Lauder Lindsay, M.D., F.L.S., Honorary Fellow of the Philosophical Institute of Canterbury, New Zealand.

In 1861-62 the author visited and examined several of the Tertiary coal-measures of New Zealand; and the paper, of which this is an abstract, contains, or consists of, an epitome of his observations thereon. The collections of specimens made during his excursions, with relative maps and other illustrations, were exhibited to the Society at their Conversazione of 25th February 1863. A suite of coal specimens was submitted to chemical analysis by Professor Murray Thomson, the results of which are included in the paper.

The Tertiary coals of Otago are described : as being typical or representative of those of the other New Zealand provinces. Their characters or qualities are contrasted with those of the

1. Tertiary Coals of Auckland and Nelson, New Zealand.

2. Tertiary Coals of Europe.

Glanzkohle of Germany.

Brown Coals, or Lignites, of

a. The Danube, Hungary, and Transylvania.

$b$. Bohemia and the Rhine.

c. Bovey-Tracey, Devonshire.

Surturbrand of Iceland.

3. Mesozoic and Palceozoic Coals of Canterbury and Nelson, New Zealand.

4. Paloozoic Coals of New South Wales and Britain.

I. Topography and Extent.-Tertiary coal deposits occur more or less abundantly in most of the New Zealand provinces; especially, however, in Otago, Nelson, Canterbury, and Auckland. Occasionally they form belts extending for great distances, sometimes as much as fifty to one hundred miles, along sea-coasts or river banks. More generally, they are localised in isolated or circumscribed inland basins. Usually they occupy plains or valleys at low elevations. Sometimes, however, they are to be found at heights of several hundred, or even thousand, feet on the flanks of hills. 
II. Origin of the Coal.-In different localities, and under different circumstances, it has at one time, apparently, consisted of drift wood and leaves; of peat bog, marsh, littoral or forest vegetation submerged in situ and subsequently re-elevated; or of marine vegetation (kelp) subsequently elevated. It has been found mainly in ancient lakes, estuaries, bays, fjords, coasts, or seas. Its associated strata present frequently, if not usually, alternations of marine (shell and kelp beds) with terrestrial deposits (dicotyledonous leaf or fern beds); indicating the occurrence of repeated and irregular oscillations of the relative levels of land and water during their deposition.

III. Stratigraphical Relations.-The best class of coals is referable to the Lower or older group of the Tertiary system; belonging, however, to different ages in this group.

Lignites, jet, and fossilised wood occur also in all the newer or superjacent Tertiaries, as well as the post-tertiary strata; while drift wood and submerged forests may be seen in process of fossilisation at the present day.

Not unfrequently the coal-beds rest immediately on the fundamental rock of the country, which is usually metamorphic slate, (probably of Silurian age), though sometimes granite.

The coal strata are frequently disturbed by eruptive or intrusive Trappean rocks of Newer Tertiary age, which sometimes tilt them up vertically, or throw them completely over. They are pierced likewise by Trap-dykes, and characterised by faults or dislocations resembling-save, perhaps, as to the scale on which they occur,-those of our own Palæozoic coal-measures. These Traps sometimes coke or cinder the immediately adjacent coal; more frequently, perhaps, the lithological character of the latter is unaffected.

\section{Associated Strata-}

a. Conglomerates (locally known as "gravels" or "cements"), usually coarse and quartzose; frequently of a plum-pudding stone character; generally ferruginous ; passing into

b. Grits, which again graduate into sandstones. Some of the latter are sufficiently hard and pure to be useful 
building stones. Occasionally they are carbonaceous; or they are impregnated, or intermixed, with magnetic iron.

c. Clays, frequently arenaceous or carbonaceous, or both; sometimes ferruginous; occasionally white and pure. They include every variety of kaolin, plastic or potter's, pipe, fire, and brick clays; and ochres or ferruginous earths; many of which are suitable for utilisation in the industrial arts.

d. Shales, also generally arenaceous or carbonaceous, or both ; sometimes richly fossiliferous, containing especially leaves (of exogenous trees and ferns) beautifully preserved.

The coal-beds are frequently directly overlaid or roofed by Newer or upper Tertiary strata; consisting usually of various conglomerates or gravels, sands and clays.

\section{Contained Minerals-}

a. Various Fossil Resins, similar to those which occur in the brown coals of Germany. To the settlers they are generically known as Kauri gum, and are considered identical with the fossil resin so called in the North Island -which is generally regarded as the produce of the existing Dammara australis Lambert (N. O. Coniferoe). They include Retinite and Ozokerite.

b. Iron Pyrites (including Marcasite); Sulphate of Iron; Clay Ironstone nodules.

c. Sulphur, generally impregnating sands or sandstones; clays or mudstones.

d. Quartz, as an impurity.

e. Jet; and vegetable débris in the form of Mineral Charcoal.

VI. Lithological or Physical Characters.-Hand-specimens exhibit all gradations between Lignite, Brown Coal, Pitch Coal, Cannel or Parrot, and Common British Domestic, Coal. Their texture, fracture, and lustre consequently vary extremely. Generally they are earthy and massive; occasionally laminated; splinter readily on exposure; do not cake in burning; colour and streak, brown to black; specific 
gravity, 1250 to 1300 ; ash generally light like that of wood; colour various shades of white, gray or buff; coke dull to iridescent.

VII. Chemical Constitution.-The following, which is the mean (in round numbers) of numerous analyses, by various chemists, of the Tertiary coals of different parts of the New Zealand Islands, may be held to represent their average composition :-

a. Proximate Constituents-

Coke

Carbon in coke (or fixed carbon),

45 per cent.

Volatile matter (hydro-carbons), .

Ash,

(Components-Silica, alumina, iron, magnesia, and lime.)

Water of constitution,

Gas, cubic feet per ton 4000

Oil, gallons per ton,

b. C'ltimate Elements-

Carbon, .

60 per cent.

Hydrogen,

Nitrogen, . 1

Oxygen, .

Sulphur, .

VIII. Commercial Value.-The following are defects in most, if not all, of the Tertiary coals of New Zealand :-

a. Proportion of water or moisture they contain: frequently 20 to 30 per cent.

b. Comparatively large amount of ash.

c. Comparatively large amount of sulphur (in pyrites), giving rise to a disagreeable odour during combustion.

d. Occasional presence of lime, which gives the quality of fusibility.

$e$. Tendêncy to fall to dust or "small" on exposure or desiccation.

$f$. Burn well only when associated with some more inflammable fuel, such as wood, peat, or Palæozoic coal.

Nevertheless, in the absence, or with a mixture, of fuel of a superior kind, this class of coal is, or may be, used as a domestic fue], voL. v. 
as well as in various branches of local manufacture, such as brick and pottery making, and metallurgic processes. Its use is, and is likely to continue, strictly local. At present it is employed as a domestic fuel, mostly on the gold-fields, where it abounds, and where fuel of a better class is scarce, if at all to be bad; or, intermixed with better fuel, by the poorer classes in large towns. It cannot compete, either as a domestic, steam, or other fuel, with New South Wales or British coals (Palæozoic), which uniformly command a higher price, and occupy a superior position, in all the New Zealand markets.

In all the large towns of New Zealand, especially in Dunedin, Christchurch, Nelson, and Auckland, there is now a comparatively good supply of both local and foreign coals. The market prices of the former vary according as they are delivered at the pit-mouth or in the towns; and those of the latter as they are delivered in the towns, or from the ships' sides in harbours or roadsteads.

The market prices of New Zealand Tertiary coals vary from 7s. $6 \mathrm{~d}$. to $35 \mathrm{~s}$.- - average, $10 \mathrm{~s}$. to $15 \mathrm{~s}$.- - per ton, delivered at the pit; and $40 \mathrm{~s}$. to $50 \mathrm{~s}$. - average, $45 \mathrm{~s}$.- - delivered in towns. Those of Newcastle (New South Wales), or Newcastle (English) coal, range from 40 s. to 80 s. per ton, according as they are delivered from the ship or in town.

IX. Produce of the Collieries.-As yet labour is limited and dear, and machinery defective; so that the highest yield at present is 100 to 150 tons per week (Fairfield Colliery, about six miles southward of Dunedin, Otago); the average elsewhere being 50 to 100 tons.

X. Flora of the Coal Measures. - Consists chiefly of the wood and leaves of exogenous trees, probably in great measure coniferous; and of ferns. The leaves include those of species of the following genera :-

Fagus,

Loranthophyllum,

The general Tertiary flora comprises-

a. The wood of various conifers, perhaps including the Kauri pine, which still exists, though within a limited area, in 
the North Island; and of other exogenous trees:-frequently silicified like the fossil wood of Antigua.

$b$. The leaves of various exogenous trees of the orders apparently of Lauracece and Cycadaceoe (genera allied to Laurus and $Z$ amia)-frequently, like the wood, beautifully silicified and preserved; of endogenous trees, chiefly of the family Palmacece; and of arborescent or large-fronded ferns.

Most of the fossil plants of the New Zealand Tertiaries are apparently extinct species; but, as in the parallel case of the fauna, a few may be referable to living forms.

XI. Fauna of the Coal Measures.-Mostly marine, includinga. Cetacece; bones.

b. Fish of the shark family (teeth): genera Lamna, Carcharias, Oxyrhina.

c. Echinoderms : Brissus, Schizaster, Hemipatagus.

d. Mollusca: species of the following genera:-

Ostrea,
Pecten,
Terebratula,
Natica,
Voluta,
Purpura,
Trochita,

Turbo, Crassatella, Dentalium, Struthiolaria, Scalaria, Waldheimia.

The general Tertiary Fauna includes in addition :-

$\left.\begin{array}{l|l}\begin{array}{l}\text { Cardium, } \\ \text { Cuculloca, } \\ \text { Mytilus, }\end{array} & \begin{array}{l}\text { Cyrena } \\ \text { Melania }\end{array}\end{array}\right\}$ fresh-water.

While the major portion are extinct species, some are identical with existing forms.

XII. Fossilisation of Vegetation at the present clay.-Instances are given of Tree Beds at various depths below the soil, and at various elevations on the mountains: of the fossilisation of drift-rood, leaves and seeds in swamp clays: of the submergence of Kauri or other orests-that are being, or have been, converted into Lignite on the western coasts (which are undergoing a process of subsidence): 
and of the overwhelming of existing forests by sea-sand on the eastern coasts (which exhibit phenomena of elevation).

Within an area of a few hundred yards on the Greenisland coast of Otago, the sand-dunes may be seen encroaching on the forest, which consists mainly of gigantic conifers : of other exogenous trees of the natural orders-

\begin{tabular}{l|l} 
Myrtacece, & Violariece, \\
Araliacece, & Pittosporece, \\
Leguminoso, & Malvaceo, \\
Onagrarice, & Tiliacees, \\
Magnoliacece, & Cornece:
\end{tabular}

of palm-like and shrubby Liliacees; and of arborescent Ferns: while they are also covering in marshes and lagoons, whose vegetation consists chiefly of littoral Grasses and Cyperaceae : fresh-water aquatics; salt-marsh plants : and marine Algoe.

The following Donations were laid on the table :-

Bulletin de L'Académie Royale des Sciences, des Lettres, et des Beaux-Arts de Belgique, No. 12. Bruxelles, 1864. 8vo.From the Academy.

Natuurkundige Verhandelingen van de Hollandsche Maatschappij der Wetenschappen te Haarlem. XIX ${ }^{e}$ Deel, XXI $I^{e}$ Deel, $1^{\circ}$ Stuk. 4to. Haarlem, 1864.-From the Society.

Sitzungsberichte der Konigl. Bayer. Akademie der Wissenschaften zu Munchen, 1864. II., Heft 2. Munchen, 1864. 8vo.From the Academy.

Report of the Proceedings of the Geological and Polytechnic Society of the West Riding of Yorkshire for 1863-64. 8vo. Leeds, 1864.-From the Society.

On the Early History of Leeds. By Thomas Wright, Esq., M.A. 8vo. Leeds, 1864.-From the same.

Forty-fourth Report of the Leeds Philosophical and Literary Society. 8vo. Leeds, 1864.-From the Society.

Thoughts on the Influence of Ether in the Solar System, its relations to the Zodiacal Light, Comets, the Seasons, and periodical Shooting Stars. By Alexander Wilcocks, M.D. 4to. Philadelphia, 1864.-From the Author. 
Die Fossilen Mollusken des Tertiær-Beckens von Wien. Von Dr M. Hörnes. Band II. 5, 6. 4to. Wien, 1865.-From the Author.

Monthly Notices of the Royal Astronomical Society, Vol. XXV. No. 3. 8vo. London, 1865.-From the Society.

Letter from John Davy, M.D., F.R.S., addressed to the editors of the Philosophical Magazine, in reply to a certain charge made by Charles Babbage, Esq., F.R.S., against the late Sir Humphry Davy, when President of the Royal Society. 8vo. -From Dr Davy.

Proceedings of the Natural History Society of Dublin for 1863-64.

Vol. IV. Part II. 8vo. Dublin, 1865.-From the Society.

The American Journal of Science and Arts, Vol. XXXIX. No. 115. 8vo. New Haven, 1865.-From the Editors.

The Quarterly Journal of the Geological Society, Vol. XXI. Part I. 8vo. London, 1865.-From the Society.

The Journal of the Linnean Society, Vol. VIII. No. 32, Botany. 8vo. London, 1865.-From the Society.

Reale Istituto Lombardo di Scienze e Lettere-Rendiconti-Classe di Scienze Matematiche e Naturali. Vol. I. Fasc. 7, 8. Classe di Lettere e Scienze Morale e Politiche. Vol. I. Fasc. 7. 8ro. Milano, 1864.-From the Institute.

Solenni Adunanze del Reale Istituto Lombardo di Scienze e

Lettere, Adunanza del 7 Agosto 1864 . 8vo. Milano, 1864.

-From the Institute.

Journal of the Chemical Society, January 1865. 8vo. London, 1865.-From the Society.

Monday, 6th March 1865.

Sir DAVID BREWSTER, President, in the Chair.

1. On the World as a Dynamical and Immaterial World. By Robert S. Wyld, Edinburgh.

What is matter? has been the question of philosophy from the earliest times. The author of this paper referred to the specula- 